\title{
Aerosol-cloud interaction determined by both in situ and satellite data over a northern high-latitude site
}

\author{
H. Lihavainen ${ }^{1}$, V.-M. Kerminen ${ }^{1}$, and L. A. Remer ${ }^{2}$ \\ ${ }^{1}$ Finnish Meteorological Institute, P.O. Box 503, 00101, Helsinki, Finland \\ ${ }^{2}$ NASA Goddard Space Flight Center, Greenbelt, MD, 20771, USA
}

Received: 4 November 2009 - Published in Atmos. Chem. Phys. Discuss.: 21 December 2009

Revised: 23 July 2010 - Accepted: 18 November 2010 - Published: 24 November 2010

\begin{abstract}
The first aerosol indirect effect over a clean, northern high-latitude site was investigated by determining the aerosol cloud interaction (ACI) using three different approaches; ground-based in situ measurements, combined ground-based in situ measurements and satellite retrievals and using only satellite retrievals. The obtained values of ACI were highest for in situ ground-based data, clearly lower for combined ground-based and satellite data, and lowest for data relying solely on satellite retrievals. One of the key findings of this study was the high sensitivity of ACI to the definition of the aerosol burden. We showed that at least a part of the variability in ACI can be explained by how different investigators have related different cloud properties to "aerosol burden".
\end{abstract}

\section{Introduction}

Atmospheric aerosol particles influence clouds, and thereby the Earth's climate, by altering the albedo, lifetime and precipitation patterns of clouds (e.g. Twomey, 1974; Lohmann and Feichter, 2005; Stevens and Feingold, 2009). Collectively, these effects are called aerosol indirect effects. The first aerosol indirect refers to the situation in which a cloud liquid path is held constant and additional particles are introduced into the cloud, resulting in more numerous but smaller cloud droplets and a more reflective cloud.

The magnitude of the first indirect effect in the global atmosphere is poorly quantified (Lohman and Feichter, 2005; Penner et al., 2006; Quaas et al., 2008, 2009). Several reasons for this can be identified. Firstly, the initial activation of aerosol particles into cloud droplets depends in a complicated manner on the aerosol particle population and cloud updraft

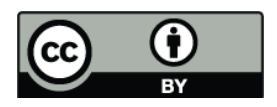

Correspondence to: $\mathrm{H}$. Lihavainen (heikki.lihavainen@fmi.fi) velocity (McFiggans et al., 2006; Reutter et al., 2009). Secondly, the cloud droplet number concentration and size distribution evolve over the cloud lifetime due to mixing and many other processes (e.g. Liu et al., 2008; Wang et al., 2009). Thirdly, measuring cloud microphysical and optical properties accurately is challenging, especially what it comes to different remote sensing techniques (e.g. Brenquir et al., 2003; McComiskey et al., 2009). Finally, it has not been entirely clear how the first indirect effect should be determined, or interpreted, from atmospheric measurements (Shao and Liu, 2006, 2009; Kim et al., 2008).

A widely-used metric used in the experimental investigation of the first indirect effect is the aerosol cloud interaction (ACI) that relates the cloud optical depth, droplet effective radius or droplet number concentration to the aerosol burden at a constant cloud liquid water path (Feingold et al., 2001). In this study, we will investigate the first indirect effect over a clean, northern high-latitude site. By determining the value of ACI with three different approaches that rely on groundbased in situ measurements and satellite retrievals, we are searching for an answer to the following questions: (1) can we detect the first indirect effect by all these methods at our site?, (2) do these methods produce similar values for ACI, and if not, why?, (3) is the value of ACI is affected by the definition of aerosol burden, and (4) what implications our findings might have on future studies on this subject.

\section{Materials and methods}

\subsection{Measurements}

The data analyzed here include different data sets and approaches. Some of these have been published elsewhere, so only a brief description is given here. A general overview of the ground site and typical conditions there has been given by Hatakka et al. (2003). 


\subsubsection{Ground based in-situ measurements}

The data set 1, called "Cloud cases", is based on measurements conducted between 2000 and 2002 at the Pallas area in northern Finland (Komppula et al., 2005). The approach takes advantage of two stations with horizontal distance of $6 \mathrm{~km}$ at different elevations. The higher-altitude station, Sammaltunturi (565 m a.s.), is inside a cloud about $5 \%$ of the time, whereas the lower-altitude station, Matorova (340 m a.s.1), is always below the cloud layer. There are two similar Differential Mobility Particle Sizer (DMPS) measuring particles in a dry size range $7-500 \mathrm{~nm}$ with 30 discrete size bins. The size distribution analyzed here are for individual cloud cases lasting from a few hours to a few days. The measurement systems and data analyses have been described in detail by Komppula et al. (2005).

The data set 2, "First PaCE" (The First Pallas Cloud Experiment), is based on an intensive measurement campaign carried out in the fall of 2004 in the Pallas area. The basic measurement approach is the same as in the data set "Cloud cases", but there were some additional measurements at both stations. For example, the cloud droplet number size disteribution was measured directly with a Forward Scattering Spectrometer Probe (FSSP) in Sammaltunturi. Data from the DMPS systems analyzed here are one-hour averages. More details on the measurement systems and data analyses can be found in Lihavainen et al. (2008).

The data set 3, "Second PaCE"(The Second Pallas Cloud Experiment), is based on an intensive measurement campaign conducted in the fall of 2005 in the Pallas area. The measurement approach is different from that during the "First PaCE" described above. The interstitial and total aerosol properties were both measured at the Sammaltunturi station using different inlet systems. The total air inlet system evaporates cloud droplets by heating. Interstitial aerosol properties were measured from a sample line that has a $\mathrm{PM}_{2.5}$ inlet nozzle. Similar DMPS systems were attached to both lines. Additional measurements included those by an aerosol mass spectrometer and FSSP. The DMPS data analyzed here are one-hour averages. More details on the measurement systems and data analyses can be found in Anttila et al. (2009) and Kivekäs et al. (2009).

The data set 4, "2007 Data", was measured during a few months beginning in August, 2007. The measurement system was similar to that during the "Second PaCE". The only additional measurement device was a FSSP that was running on the side with the DMPS systems. DMPS data analyzed here are one-hour averages.

\subsubsection{Remote sensing and ground base measurements}

For this data set (number 5), we took advantage of combining the long-term ground-based measurement at Sammaltunturi and cloud retrievals from the MODerate resolution Imaging Spectroradiometer (MODIS) on both the Aqua and
Terra platforms. The data analyzed in this context covers the years 2000-2005. The cloud properties used here are the $1 \mathrm{~km} \times 1 \mathrm{~km}$ retrieved effective radius and optical thickness (Platnick et al., 2003). Each $1 \mathrm{~km} \times 1 \mathrm{~km}$ within a radius of $20 \mathrm{~km}$ around the Sammaltunturi was connected with the closest properties of $5 \mathrm{~km} \times 5 \mathrm{~km}$ data sets (like cloud top pressure). Each data point from MODIS was combined with the closest one-hour average data measured at Sammaltunturi, provided that it met the following requirements:

a. The cloud was a low-level or boundary-layer cloud, with the limiting cloud top pressure set to $780 \mathrm{hPa}$.

b. The liquid water path (LWP) should be constant when using the cloud droplet effective radius $\left(r_{\mathrm{e}}\right)$ or cloud optical thickness (COT) in defining the aerosol-cloud interaction (ACI, see Eqs. ( $1 \mathrm{a}-\mathrm{c})$ and (2) below). ACI was calculated over the LWP range of $50-200 \mathrm{~g} \mathrm{~m}^{-2}$ with a segregation into $10 \mathrm{~g} \mathrm{~m}^{-2}$ LWP bins.

c. The Sammaltunturi station was below the cloud base. This information we got from the visibility sensor which measures the visibility in the range from $10 \mathrm{~m}$ to $50 \mathrm{~km}$. The limiting value for one-hour average visibility was set to $30 \mathrm{~km}$.

d. Since the ground-based data sets 1-4 are mostly from late summer and fall, the analysis here was restricted to days of year (doy) larger than 150 .

e. The aerosol optical depth (AOD) is larger than 0.0 (for remote sensing study only).

f. No rain was observed at Sammaltunturi.

g. Multi-layered clouds were removed.

\subsubsection{Remote sensing}

For this data set (number 6), we expanded the analysis from the local stations and took again advantage of both MODIS aerosol, collection 5, (Levy et al., 2007) and cloud (Platnick et al., 2003) retrievals from both Terra and Aqua platforms. The aerosol $(10 \times 10 \mathrm{~km}$ resolution $)$ and cloud properties $(1 \mathrm{~km} \times 1 \mathrm{~km}$ or $5 \mathrm{~km} \times 5 \mathrm{~km}$, depending on retrieval $)$ were averaged over a $1^{\circ} \times 1^{\circ}$ grid. The area for which the calculations were done was from $65^{\circ}$ to $70^{\circ} \mathrm{N}$ and from $20^{\circ}$ to $30^{\circ} \mathrm{E}$. The time period was from 2003 to 2005 . The same limiting values were applied for the cloud top pressure, seasons and LWP as for the data set 5 .

\subsection{Determination of the aerosol-cloud interaction}

The first aerosol indirect effect is defined as the change in observed cloud optical or microphysical properties (optical depth, albedo or cloud droplet effective radius) as a function of the change in the aerosol load (e.g. Twomey, 1974). When 
the number concentration of aerosol particles capable of acting as cloud condensation nuclei increases, also the number concentration of cloud droplets is expected to increase. If the liquid water content of the cloud stays constant, the increase in the cloud droplet number concentration results in smaller average droplet size and thereby in a larger cloud optical depth and albedo.

The aerosol-cloud interaction (ACI) is usually calculated using one of the following relations (Feingold et al., 2001; McComiskey et al., 2009):

$$
\begin{aligned}
\mathrm{ACI}_{N_{\mathrm{d}}} & =\frac{1}{3} \frac{d \ln N_{\mathrm{d}}}{d \ln \alpha}, \\
\mathrm{ACI}_{\mathrm{COT}} & =\left.\frac{\partial \ln C \mathrm{OT}}{\partial \ln \alpha}\right|_{\mathrm{LWP}}, \\
\mathrm{ACI}_{r_{\mathrm{e}}} & =-\left.\frac{\partial \ln r_{\mathrm{e}}}{\partial \ln \alpha}\right|_{\mathrm{LWP}} .
\end{aligned}
$$

Here, $N_{\mathrm{d}}$ is the cloud droplet number concentration, COT is the cloud optical depth, $r_{\mathrm{e}}$ is the cloud droplet effective radius, LWP is the cloud liquid water path, and $\alpha$ in some proxy for the aerosol burden such as the aerosol optical depth, total number concentration of aerosol particles or aerosol light scattering coefficient. Note that the partial derivatives in Eq. (1b) and (1c) must be calculated at the constant LWP.

Aerosol number size distribution measurements give us an opportunity to investigate the effects of particle size on the aerosol burden and ACI. Therefore, when analysing the ground-based data, or when combining ground-based in-situ measurements with retrieved cloud properties from remote sensing, we calculated ACI for a number of different cut-off particle diameters $d_{k}$ :

$$
\operatorname{ACI}_{N_{\mathrm{d}}}\left(d_{k}\right)=\frac{1}{3} \frac{d \ln N_{\mathrm{d}}}{d \ln \left(\sum_{i=k}^{30} N_{i}\right)},
$$

$$
\operatorname{ACI}_{\mathrm{COT}}\left(d_{k}\right)=\left.\frac{\partial \operatorname{lnCOT}}{\partial \ln \left(\sum_{i=k}^{30} N_{i}\right)}\right|_{\mathrm{LWP}},
$$

$$
\operatorname{ACI}_{r_{\mathrm{e}}}\left(d_{k}\right)=-\left.\frac{\partial \ln r_{\mathrm{e}}}{\partial \ln \left(\sum_{i=k}^{30} N_{i}\right)}\right|_{\text {LWP }} .
$$

Here, $N_{i}$ is the particle number concentration in the size bin $i$ measured by the DMPS, and the index $k$ varies between 1 $\left(d_{1} \approx 10 \mathrm{~nm}\right)$ and $28\left(d_{28} \approx 370 \mathrm{~nm}\right)$. In practise, this means that the aerosol burden used for calculating $\operatorname{ACI}\left(d_{k}\right)$ is assumed to be the total particle number concentration in the diameter range $d_{k}$ to $500 \mathrm{~nm}$. Eqs. (1) and (2) are calculated as a slope of linear regression of $\ln \mathrm{N}_{\mathrm{d}}$ as a function of $\ln \alpha$, or $\ln$ COT as a function of $\ln \alpha$ etc.

\section{Results and discussion}

Long-term average total particle number and sub-micron volume concentration at our measurement site are equal to $670 \mathrm{~cm}^{-3}$ and $1.0 \mu \mathrm{m}^{-3} \mathrm{~cm}^{-3}$, respectively (Lihavainen et al., 2008). This demonstrates that the site represents a very clean continental location. Measured cloud droplet number concentrations averaged between about 130 and $180 \mathrm{~cm}^{-3}$ for the data sets $1-4$, which are at the lower end of values reported for continental clouds (Miles et al., 2002). During the "First" and "Second PaCE", aerosol and cloud water chemical composition were also studied (Lihavainen et al., 2008). These quantities were found to vary considerably with varying air mass types. In Arctic air masses, major inorganic ions in aerosol particles and cloud water were found to be sodium and chloride, whereas in continental air masses sulphate was the dominant inorganic ion. The contribution of organic compounds to the aerosol population tends to increase with increasing travel time over the boreal forest in marine air masses (Tunved et al., 2006; Lihavainen et al., 2009). Application of an adiabatic cloud parcel model to cloud data measured during the "First PaCE" demonstrated that typical air updraft velocities for clouds observed at Pallas are in the range of $0.1-0.7 \mathrm{~m} \mathrm{~s}^{-1}$ (Anttila et al., 2009).

In the following, we will apply three different methods to estimate ACI at our site and then compare the results with available literature data.

\subsection{Ground-based data only}

Here, we used data sets 1-4 and Eq. (2a) to investigate the behavior of ACI. To start with, let us consider a lower size limit of 50-150 nm when calculating aerosol-cloud interaction. In that case, $\operatorname{ACI}\left(d_{k}\right)$ varied in the range 0.2-0.3 depending on the exact value of $d_{k}$ and used data set (Fig. 1a). The correlation between different data points used to calculate ACI was high $(\sim 0.9$; Fig. $1 \mathrm{~b})$, which is at least partly due to the fact that $d_{k}$ is close to the "dry" particle diameter that separates activated cloud droplets from cloud interstitial particles at our measurement site (Komppula et al., 2005). When these two diameters are close to each other, the particle population contributing to cloud droplet activation is roughly the same as the one used to calculate the aerosol burden. Values of ACI were clearly the lowest for the data set 3 in the range $d_{k}=50-150 \mathrm{~nm}$. A major contributing factor for this feature was probably the different shape of the average particle number size distribution between the data set 3 and other data sets (Fig. 1c). Data set three had also the largest variation in the accumulation mode (Fig. 1d), which may also contribute to higher ACI values at larger particle sizes. 

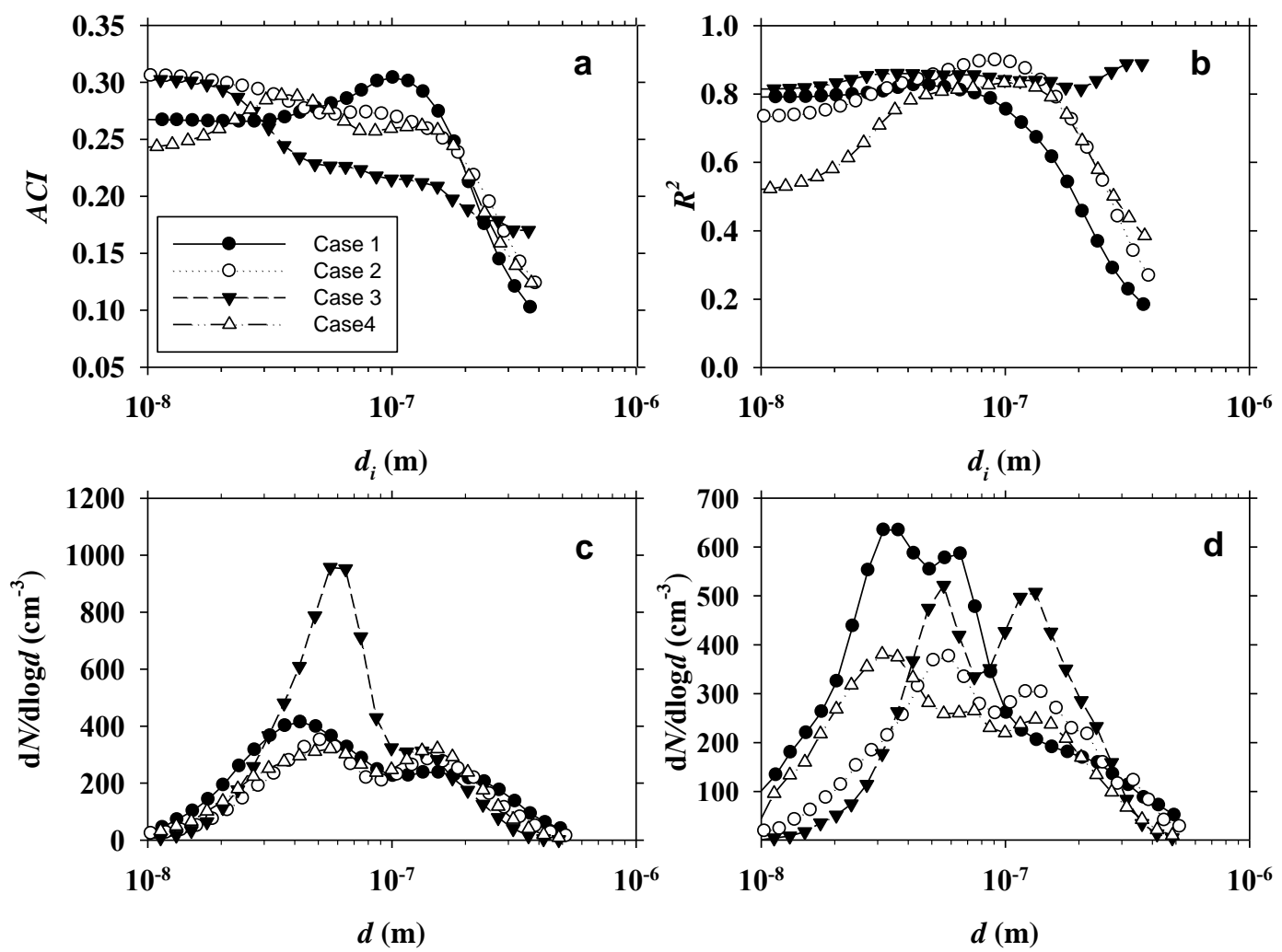

Fig. 1. (a) Aerosol-cloud interaction (ACI) from in situ data in different cases as a function of particle size. (b) Correlation coefficient $\left(R^{2}\right)$ between cloud and aerosol parameters as a function of particle size. (c) Average particle number size distribution in different cases, on the $\mathrm{x}$-axis is the size and $\mathrm{y}$-axis is the concentration. (d) Standard deviation of the particle number size distribution in each case, on the $\mathrm{x}$-axis the size and $y$-axis is the standard deviation.

Above $150 \mathrm{~nm}, \operatorname{ACI}\left(d_{k}\right)$ decreased rapidly with increasing $d_{k}$, reaching values between about 0.1 and 0.2 at $d_{k}$ of $370 \mathrm{~nm}$ (Fig. 1a). The apparently lower values of ACI for $d_{k}>150 \mathrm{~nm}$ do not indicate weaker aerosol-cloud interaction, but rather demonstrate that the sub-population of aerosol particles used to calculate the aerosol burden is not anymore a good representative of the one that participates in cloud droplet activation. This view is supported by simultaneous strong decrease in the correlation between different data points used to calculate ACI (Fig. 1b, exception the data set 3 ).

When $d_{k}$ was decreased below $50 \mathrm{~nm}$, values of ACI remained high, mostly above 0.25 (Fig. 1a). The main reason for this is probably that sub-50 nm particles did not give a big contribution to the total particle number concentration for the data sets 1-4 (Fig. 1c). Furthermore, the variability of the aerosol number size distribution was relatively low for these data sets (Fig. 1d).

\subsection{Combined ground-based and satellite data}

For the data set 5 discussed here, values of ACI were calculated using either COT (Eq. 2b) or $r_{\mathrm{e}}$ (Eq. 2c) obtained from satellite data as the cloud property. The aerosol burden

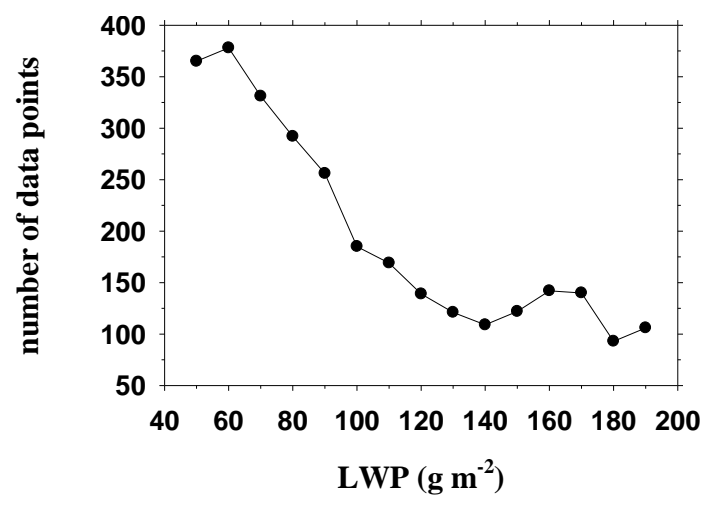

Fig. 2. Number of data points combining ground based in-situ measurement with satellite cloud retrievals as a function liquid water path (LWP). LWP was derived from satellite retrievals.

was taken from ground-based particle number size distribution measurements in the same way as in Sect. 3.1. After filtering the data according to the criteria given in Sect. 2.1.2, the number of data points left into diffent LWP bins varied between about 100 and 400 (Fig. 2). 

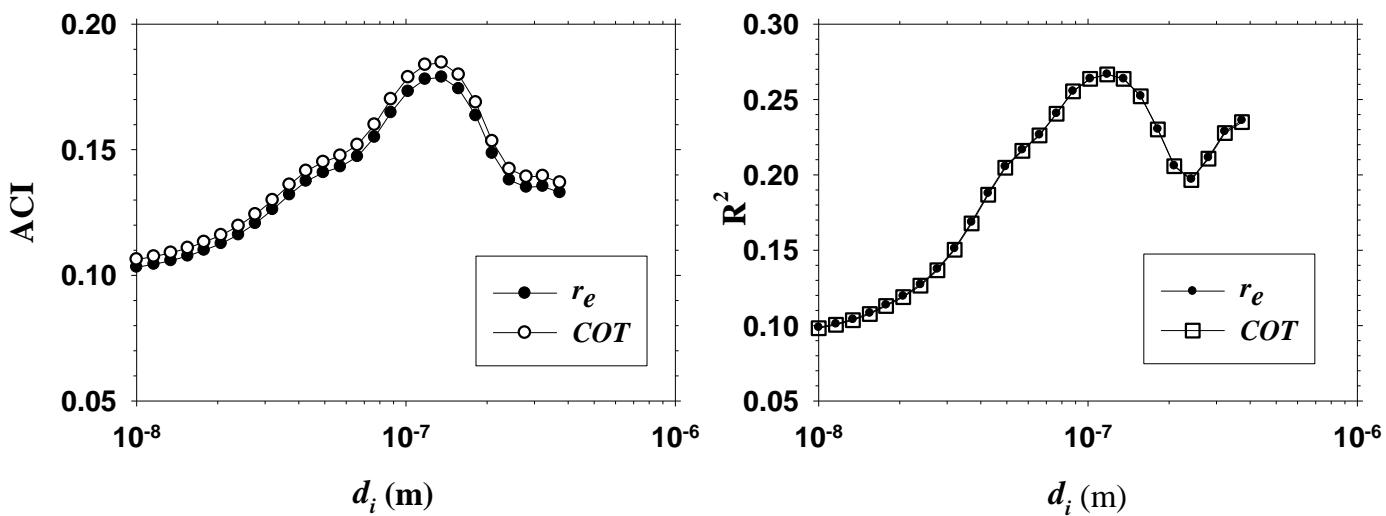

Fig. 3. On the left: Aerosol-cloud interaction (ACI) from a combination of remote sensing cloud properties and in situ measures of aerosol burden as a function of particle size. On the right: correlation coefficient $\left(R^{2}\right)$ between cloud and aerosol parameters as a function of particle size.
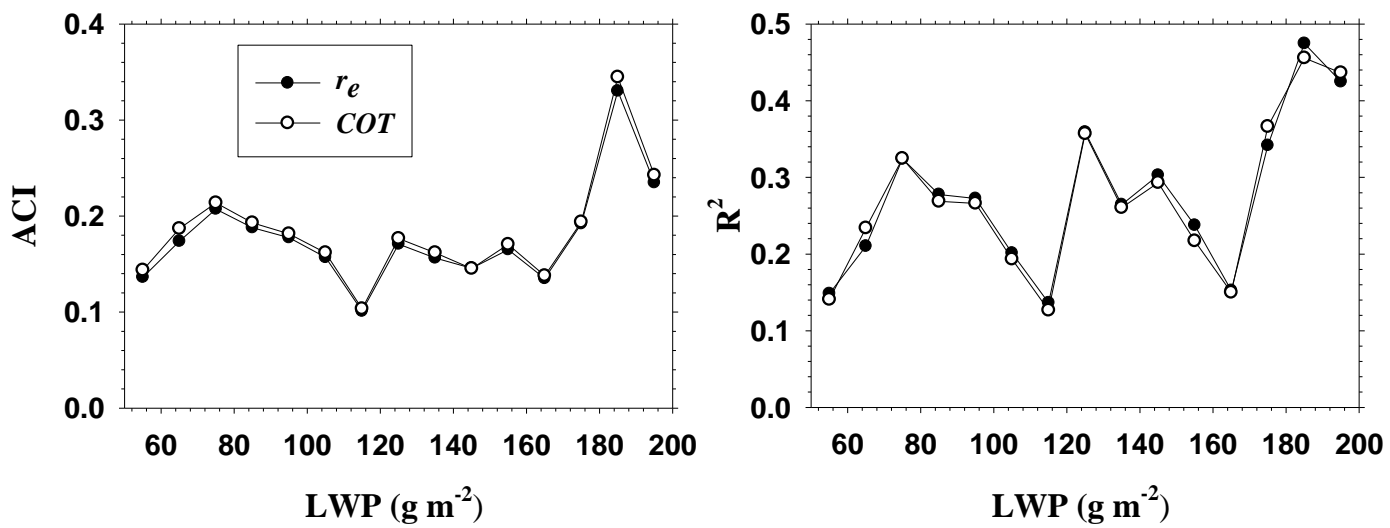

Fig. 4. On the left Aerosol-cloud interaction (ACI) from a combination of remote sensing cloud properties and in situ measures of aerosol burden as a function of Liquid Water Path (LWP) measured by satellite. On the right: Correlation coefficient $\left(R^{2}\right)$ between cloud and aerosol parameters as a function of LWP. ACI is calculated with concentration of particles larger than $130 \mathrm{~nm}$.

The values of ACI varied between about 0.10 and 0.18 depending on the cut-off size $d_{k}$, with practically no difference between the two approaches (Fig. 3). These values are substantially lower than those obtained from the data sets 1-4 (Fig. 1a), as are also the correlation coefficients (Figs. 1b and 3 ). Potential reasons for this feature include (i) the reduction of the value of ACI resulting from the spatial or other kind of averaging related to the satellite data (see, e.g. Sekiguchi et al., 2003; McComiskey et al., 2009), (ii) and the fact that the aerosol and cloud properties used for calculating ACI were not co-located. In order to find out whether averaging over a broad LWP range might influence our results, we determined the dependence of ACI on LWP (Fig. 4). This was made for the cut-off diameter $d_{k}$ of $130 \mathrm{~nm}$, which is the size at which ACI appeared to have a maximum (Fig. 3). No clear LWP dependence in the value of ACI, neither in the correlation coefficient, was observed. This is in contrary to observations by McComiskey et al. (2009) who found that $\mathrm{ACI}_{\mathrm{Cot}}$ decreased from about 0.22 to about 0.10 when the LWP increased from
50 to $150 \mathrm{~g} \mathrm{~m}^{-2}$. Our data show an increase in ACI between after LWP of $160 \mathrm{~g} \mathrm{~m}^{-2}$, which is most probably just a coincidence due to the low number and quality of data.

Contrary to data sets $1-4$, values of ACI in the data set 5 decreased below 0.15 when the lower limit of particle sizes used to calculate the aerosol burden went below $60 \mathrm{~nm}$ (Fig. 3). The probable reason for this behaviour was the relatively large number concentration of particles smaller than $60 \mathrm{~nm}$ and especially its large variability. By looking at individual particle number size distributions, particles in this size range could be traced to new-particle formation events, which is a common phenomenon around our measurement site during late summer and early fall (Dal Maso et al., 2007). Practically no new-particle formation events were observed in the data sets $1-4$, since the weather conditions that cause the Sammaltunturi to be within a cloud are not generally favourable to atmospheric nucleation. 

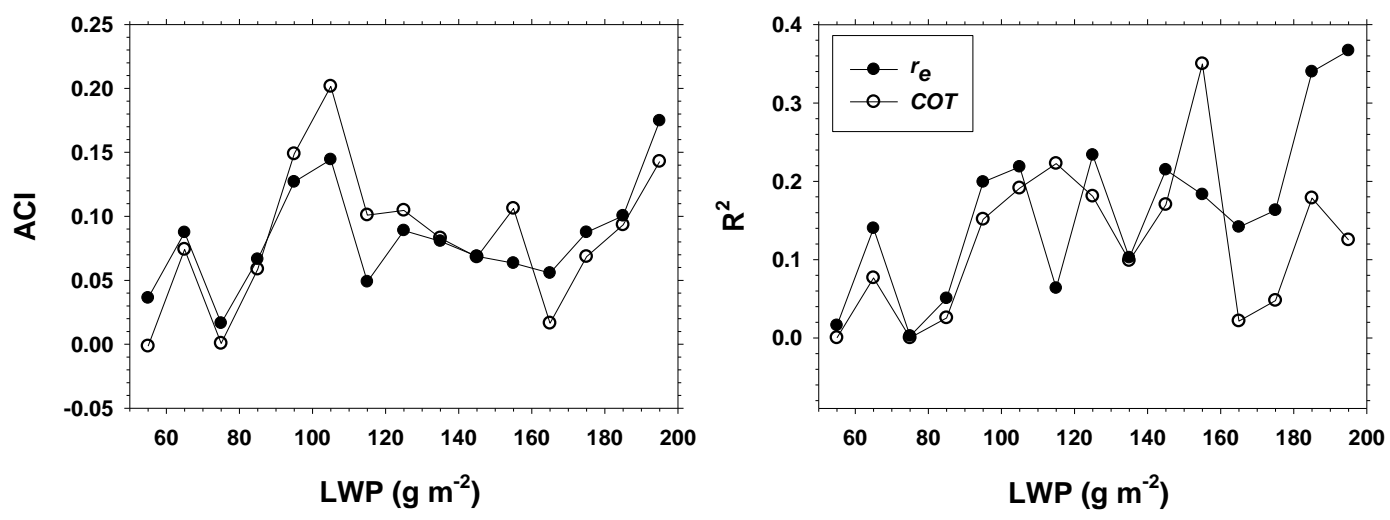

Fig. 5. On the left Aerosol-cloud interaction (ACI) calculated using only remote sensing retrievals for both cloud and aerosol properties as a function of Liquid Water Path (LWP). On the right: Correlation coefficient $\left(R^{2}\right)$ between cloud and aerosol parameters as a function of LWP. LWP is also calculated from remote sensing retrievals.

\subsection{Satellite data only}

Here, we relied solely on satellite data for determining ACI. The values of $r_{\mathrm{e}}$ and COT were obtained as in Sect. 3.2, whereas the aerosol burden was replaced with the retrieved aerosol optical depth (AOD). The AOD is a good quantity for this purpose because it is measured by several different techniques, and because its suitability to trace cloud condensation nuclei concentrations have been discussed a lot (Andreae, 2009). A total of 909 data points were obtained for LWP bins of size $10 \mathrm{~g} \mathrm{~m}^{-2}$ from 50 to $200 \mathrm{~g} \mathrm{~m}^{-2}$. At least 10 data points in each bin were required to accept the bin to be taken into consideration.

Figure 5 shows the dependences of $\mathrm{ACI}_{r_{\mathrm{e}}}$ and $\mathrm{ACI}_{\mathrm{COT}}$ on LWP. $\mathrm{ACI}_{r_{\mathrm{e}}}$ varied between 0.01 and 0.17 and $\mathrm{ACI}_{\mathrm{COT}}$ between 0.0 and 0.20 . There was no dependency on LWP value on either. $R^{2}$ between $\ln r_{\mathrm{e}}$ and $\ln$ AOD as well as between $\ln$ COT and $\ln$ AOD is also shown in Fig. 5. At lower LWP values $R^{2}$ is lower than at LWP values higher than $100 \mathrm{~g} \mathrm{~m}^{-2}$. The average ( \pm standard deviation) of $\mathrm{ACI}_{r_{\mathrm{e}}}$ is $0.09( \pm 0.04)$ and $\mathrm{ACI}_{\mathrm{COT}} 0.09( \pm 0.05)$ over the studied LWP range.

Interestingly, the value of ACI obtained for this data set is not very far from the values of $\operatorname{ACI}\left(d_{k}\right)$ in data sets 14 when taken $370 \mathrm{~nm}$ as the smallest size $\left(d_{k}\right)$ to calculate the aerosol burden. The explanation for this can be found when looking at how optical measures of the aerosol burden, such as the aerosol scattering coefficient, are related to aerosol burden determined from particle number size distributions. Aaltonen et al. (2006) investigated three years of simultaneous aerosol scattering and particle number size distribution data from our measurement site. They found that while the aerosol scattering coefficient had quite a good correlation with the total number concentration of accumulation mode particles $\left(100-500 \mathrm{~nm} ; R^{2}=0.60\right)$, the respective correlation was much better with the number concentration of particles $>200 \mathrm{~nm}$ in diameter $\left(R^{2}=0.85\right)$ and even better with that of $>300 \mathrm{~nm}$ particles $\left(R^{2}=0.93\right)$. By putting these pieces of information together, we may conclude that, at least in our measurement site, using the aerosol scattering coefficient (and therefore also AOD) as a measure of the aerosol burden is very likely to lead to too low values of ACI.

\subsection{Comparison with other studies}

The values of aerosol-cloud interaction (ACI) for our in situ ground-based measurements were mostly above 0.25 when keeping the lower size limit to calculate the aerosol burden below $100-150 \mathrm{~nm}$. In early field and model studies, the aerosol burden was frequently traced by the sulphate mass concentrations. Boucher and Lohmann (1995) combined five in situ field studies and derived an empirical relation between the cloud droplet number concentration and sulphate mass concentration. That relation corresponds to ACI of about 0.14 , which is much lower than the value obtained here. McComiskey and Feingold (2008) summarized results from seven different in situ airborne studies made for determining aerosol-cloud interaction. In five of these studies observed values of ACI were comparable to ours $(>0.20)$, whereas two other studies showed clearly lower values $(\sim 0.1)$.

By combining in situ ground-based and satellite data, and by leaving out particles smaller than $60 \mathrm{~nm}$ to calculate the aerosol burden, we obtained ACI in the range of 0.15-0.18. A few other studies have determined ACI with the help of ground-based remote sensing of clouds and aerosol scattering coefficient measurements. Reported values of $\mathrm{ACI}_{r_{\mathrm{e}}}$ have been found to be in the range of 0.13-0.19 for Arctic clouds (Garret et al., 2004), in the ranges of 0.02-0.16 (Feingold et al., 2003) and 0.04-0.17 (Kim et al., 2008) for continental clouds, and in the range of $0.02-0.18$ for marine stratus clouds (Pandithurai et al., 2009). Corresponding ranges of $\mathrm{ACI}_{\mathrm{COT}}$ have been found as $0.05-0.16$ for coastal marine clouds McComiskey et al. (2009) and 0.01-0.15 for marine stratus clouds (Pandithurai et al., 2009). Taken together, these measurements indicate that the combined use of remote 
sensing and in situ data results in value of ACI that (i) have a relatively large variability even for the same environment, (ii) are almost always smaller than 0.20 , and (iii) are clearly lower than ACI obtained from in situ measurements.

At our site, ACI determined using the satellite data was equal to 0.09 regardless of whether $r_{\mathrm{e}}$ or COT was used as a cloud property. Other satellite-based investigations have observed quite a variable range of values for ACI over different world regions (see Bulgin et al., 2008, and references therein). However, when averaging over the globe, Bulgin et al. (2008) found ACI to be in the range 0.10-0.16 during different seasons. This is line with our finding and suggests that satellite-derived values of ACI tend to be lower than those obtained using either solely by in situ data or a combination of in situ and remote sensing data.

\section{Conclusions}

In this work, we investigated the first indirect effect, or more specifically aerosol-cloud interaction (ACI), over a clean, northern high-latitude site using three different approaches. All of the approaches used were able to detect the first indirect effect at our site. The obtained values of ACI were highest for in situ ground-based data, clearly lower for combined ground-based and satellite data, and lowest for data relying solely on satellite retrievals. This feature is consistent with available literature data, even though it must be kept in mind that observed values of ACI display usually a large variability even for a single site.

Perhaps the most important of our findings was the high sensitivity of ACI to the definition of the aerosol burden. For our in situ data ACI was typically at its maximum when the sub-population of aerosol particles used to calculate the aerosol burden was roughly the same as the one participating in cloud droplet activation, which meant counting all particles down to about $100 \mathrm{~nm}$ in diameter. Optical measures of the aerosol burden do not usually fulfill this requirement so, at least for our site, using the aerosol scattering coefficient or AOD as a measure of aerosol burden would result in values of ACI that are smaller than the "real" aerosol-cloud interaction.

Besides the aerosol burden, there are number of other factors that might affect the first indirect, or the variability of ACI as determined from measurements. One influencing factor, probably also in the present study, is that aerosol and cloud properties are often not measured at the same place and time (e.g. Myhre et al., 2007; Shao and Liu, 2009). Furthermore, it is well known that the fraction of aerosol particles activating into cloud droplets depends on the air updraft velocity, shape of the particle size distribution and chemical composition of the aerosol population (e.g. McFiggans et al., 2006; Reutter et al., 2009). We observed a clear effect of the shape of the particle size distribution on the magnitude of ACI.
McComiskey and Feingold (2008) made radiative forcing calculations and estimated that narrowing the uncertainty in measures of ACI to an accuracy of 0.05 would place estimated cloud radiative forcing on "a sounder footing". This sounds challenging, especially when given the large variability in reported values of ACI. We have shown that at least a part of the variability in ACI can be explained by how different investigators have related different cloud properties to "aerosol burden". In this regard, more studies should be dedicated to explore how well various optical measures of the aerosol burden can be used to calculate ACI in different environments.

Acknowledgements. Authors would like to thank you Academy of Finland Center of Excellence program (project number 1118615), Academy of Finland Researcher training and research abroad program (project number 126276) and European Commissions 6th Framework project EUCAARI (European Integrated project on Aerosol Cloud Climate and Air Quality Interactions, No. 036833-2) for financial support.

Edited by: E. Swietlicki

\section{References}

Aaltonen, V., Lihavainen, H., Kerminen, V.-M., Komppula, M., Hatakka, J., Eneroth, K., Kulmala, M., and Viisanen, Y.: Measurements of optical properties of atmospheric aerosols in Northern Finland, Atmos. Chem. Phys., 6, 1155-1164, doi:10.5194/acp-6-1155-2006, 2006.

Andreae, M. O.: Correlation between cloud condensation nuclei concentration and aerosol optical thickness in remote and polluted regions, Atmos. Chem. Phys., 9, 543-556, doi:10.5194/acp-9-543-2009, 2009.

Anttila, T., Vaattovaara, P., Komppula, M., Hyvärinen, A.-P., Lihavainen, H., Kerminen, V.-M., and Laaksonen, A.: Sizedependent activation of aerosols into cloud droplets at a subarctic background site during the second Pallas Cloud Experiment (2nd $\mathrm{PaCE}$ ): method development and data evaluation, Atmos. Chem. Phys., 9, 4841-4854, doi:10.5194/acp-9-4841-2009, 2009.

Brenquir, J.-L., Pawlowska, H., and Schüller, L.: Cloud microphysical and radiative properties for parameterization and satellite monitoring of the indirect effect of aerosol on climate, J. Geophys. Res., 108, 8632, doi:10.1029/2002JD002682, 2003.

Boucher, O. and Lohmann, U.: The sulfate-CCN-cloud albedo effect. A sensitivity study with two general circulation models, Tellus, 47B, 281-300, 1995.

Bulgin, C. E., Palmer, P. I., Thomas, G. E., Arnold, C. P. G., Campmany, E., Carboni, E., Grainger, R. G., Poulsen, C., Siddans, R., and Lawrence, B. N.: Regional and seasonal variations of the Twomey indirect effect as observed by the ASTR-2 satellite instrument, Geophys. Res. Lett., 35, L02822, doi:10.1029/2007GL031394, 2008.

Dal Maso, M., Sogacheva, L., Aalto, P. P., Riipinen, I., Komppula, M., Tunved, P., Korhonen, L., Suur-Uski, V., Hirsikko, A., Kurtén, T., Kerminen, V.-M., Lihavainen, H., Viisanen, Y., Hansson, H.-C., and Kulmala, M: Aerosol size distribution measurements at four Nordic field stations: identification, analysis and 
trajectory analysis of new particle formation bursts, Tellus, 59B, 350-361, 2007.

Dal Maso, M., Hyvärinen, A., Komppula, M., Tunved, P., Kerminen, V.-M., Lihavainen, H., Viisanen, Y., Hansson, H.-C., and Kulmala, M.: Annual and interannual variation in boreal forest aerosol particle number and volume concentration and their connection to particle formation, Tellus, 60B, 495-508, 2008.

Feingold, G., Remer, L. A., Rmaprasad, J., and Kaufman, Y. J.: Analysis of smoke impact on clouds in Brazilian biomass burning regions: An extention of Twomey's approach, J. Geophys. Res., 106, 22907-22922, 2001.

Feingold, G., Eberhard, W. L., Veron, D. E., and Previdi, M.: First measurements of the Twomey indirect effect using ground-based remote sensors, Geophys. Res. Lett., 30, 1287, doi:10.1029/2002GL016633, 2003.

Garrett, T. J., Zhao, C., Dong, X., Mace, G. G., and Hobbs, P. V.: Effects of varying aerosol regimes on low-level Arctic stratus, Geophys. Res. Lett., 31, L17105, doi:10.1029/2004GL019928, 2004.

Hatakka, J., Aalto, T., Aaltonen, V., Aurela, M., Hakola, H., Komppula, M., Laurila, T., Lihavainen, H., Paatero, J., Salminen, K., and Viisanen, Y.: Overview of the atmospheric research activities and results at Pallas GAW station, Boreal Environ. Res., 8, 365-384, 2003.

Kim, B.-G., Schwartz, S. E., Miller, M. A., and Min, Q.: The role of adiabaticity in the aerosol first indirect effects, J. Geophys. Res., 113, D05210, doi:10.1029/2007JD008961, 2008.

Kivekäs, N., Kerminen, V.-M., Raatikainen, T., Vaattovaara, P., Laaksonen, A., and Lihavainen, H.: Physical and chemical characteristics of aerosol particles and cloud-droplet activation during the Second Pallas Cloud Experiment (Second PaCE), Boreal Env. Res., 14, 515-526, 2009.

Komppula, M., Lihavainen, H., Kerminen, V.-M., Kulmala, M., and Viisanen, Y.: Measurements of cloud droplet activation of aerosol particles at a clean subarctic background site, J. Geophys. Res., 110, D06204, doi:10.1029/2004JD005200, 2005.

Levy, R. C., Remer, L., Mattoo, S., Vermote, E., and Kaufman, Y. J.: Second-generation algorithm for retrieving aerosol properties over land from MODIS spectral reflectance, J. Geophys. Res., 112, D13211, doi:10.1029/2006JD007811, 2007.

Lihavainen, H., Kerminen, V.-M., Komppula, M., Hyvärinen, A.-P., Laakia, J., Saarikoski, S., Makkonen, U., Kivekäs, N., Hillamo, R., Kulmala, M., and Viisanen Y.: Measurements of the relation between aerosol properties and microphysics and chemistry of low level liquid water clouds in Northern Finland, Atmos. Chem. Phys., 8, 6925-6938, doi:10.5194/acp-8-6925-2008, 2008.

Lihavainen, H., Kerminen, V.-M., Tunved, P., Aaltonen, V., Arola, A., Hatakka, J., Hyvärinen, A., and Viisanen, Y.: Observational signature of the direct radiative effect by natural boreal forest aerosols and its relation to the corresponding first indirect effect, J. Geophys. Res., 114, D20206, doi:10.1029/2009JD012078, 2009.

Liu, Y., Daum, P. H., Guo, H., and Peng, Y.: Dispersion bias, dispersion effect, and the aerosol-cloud conundrum, Environ. Res. Lett., 3, 045021, doi:10.1088/1748-9326/3/4/045021, 2008.

Lohmann, U. and Feichter, J.: Global indirect aerosol effects: a review, Atmos. Chem. Phys., 5, 715-737, doi:10.5194/acp-5-7152005, 2005.

McComiskey, A. and Feingold, G.: Quantifying error in the radia- tive forcing of the first indirect effect, Geophys. Res. Lett., 35, L02810, doi:10.1029/2007GL032667, 2008.

McComiskey, A., Feingold, G., Frisch, A. S., Turner, D. D., Miller, M. A., Chiu, J. C., Min, Q., and Ogren, J. A.: An assessment of aerosol-cloud interaction in marine stratus clouds based on surface remote sensing, J. Geophys. Res., 114, D09203, doi:10.1029/2008JD011006, 2009.

McFiggans, G., Artaxo, P., Baltensperger, U., Coe, H., Facchini, M. C., Feingold, G., Fuzzi, S., Gysel, M., Laaksonen, A., Lohmann, U., Mentel, T. F., Murphy, D. M., O’Dowd, C. D., Snider, J. R., and Weingartner, E.: The effect of physical and chemical aerosol properties on warm cloud droplet activation, Atmos. Chem. Phys., 6, 2593-2649, doi:10.5194/acp-6-2593-2006, 2006.

Miles, N. L., Verlinde, J., and Clothiaux, E. E.: Cloud droplet size distributions in low-level stratiform clouds, J. Atmos. Sci., 57, 295-311, 2002.

Myhre, G., Stordal, F., Johnsrud, M., Kaufman, Y. J., Rosenfeld, D., Storelvmo, T., Kristjansson, J. E., Berntsen, T. K., Myhre, A., and Isaksen, I. S. A.: Aerosol-cloud interaction inferred from MODIS satellite data and global aerosol models, Atmos. Chem. Phys., 7, 3081-3101, doi:10.5194/acp-7-3081-2007, 2007.

Pandithurai, G., Takamura, T., Yamaguchi, J., Miyagi, K., Takano, T., Ishizaka, Y., Dipu, S., and Shimizu, A.: Aerosol effects on cloud droplet size as monitored from surface-based remote sensing over East China Sea Region, Geophys. Res. Lett., 36, L13805, doi:10.1029/2009GL038451, 2009.

Penner, J. E., Quaas, J., Storelvmo, T., Takemura, T., Boucher, O., Guo, H., Kirkevåg, A., Kristjànsson, J. E., and Seland, Ø.: Model intercomparison of indirect aerosol effects, Atmos. Chem. Phys., 6, 3391-3405, doi:10.5194/acp-6-3391-2006, 2006.

Platnick, S., King, M. D., Ackerman, S. A., Menzel, W. P., Baum, B. A., Riedi, J. C., and Frey, R. A.: The MODIS cloud products: Algorithms and examples from Terra, IEEE Trans. Geosci. Remote Sens., 41(2), 459-473, 2003.

Quaas, J., Boucher, O., Bellouin, N., and Kinne, S.: Satellite-based estimate of the direct and indirect aerosol climate forcing, J. Geophys. Res., 113, D05204, doi:10.1029/2007JD008962, 2008.

Quaas, J., Ming, Y., Menon, S., Takemura, T., Wang, M., Penner, J. E., Gettelman, A., Lohmann, U., Bellouin, N., Boucher, O., Sayer, A. M., Thomas, G. E., McComiskey, A., Feingold, G., Hoose, C., Kristjànsson, J. E., Liu, X., Balkanski, Y., Donner, L. J., Ginoux, P. A., Stier, P., Grandey, B., Feichter, J., Sednev, I., Bauer, S. E., Koch, D., Grainger, R. G., Kirkevåg, A., Iversen, T., Seland, Ø., Easter, R., Ghan, S. J., Rasch, P. J., Morrison, H., Lamarque, J.-F., Iacono, M. J., Kinne, S., and Schulz, M.: Aerosol indirect effects - general circulation model intercomparison and evaluation with satellite data, Atmos. Chem. Phys., 9, 8697-8717, doi:10.5194/acp-9-8697-2009, 2009.

Reutter, P., Su, H., Trentmann, J., Simmel, M., Rose, D., Gunthe, S. S., Wernli, H., Andreae, M. O., and Pöschl, U.: Aerosoland updraft-limited regimes of cloud droplet formation: influence of particle number, size and hygroscopicity on the activation of cloud condensation nuclei (CCN), Atmos. Chem. Phys., 9, 7067-7080, doi:10.5194/acp-9-7067-2009, 2009.

Sekiguchi, M., Nakajima, T., Suzuki, K., Kawamoto, K., Higurashi, A., Rosenfeld, D., Sano, I., and Mukai, S.: A study of the direct and indirect effects of aerosols using global satellite data sets of aerosol and cloud parameters, J. Geophys. Res., 108(D22), 4699, 
doi:10.1029/2002JD003359, 2003.

Shao, H. and Liu, G.: Influence of mixing on evaluation of the aerosol first indirect effect, Geophys. Res. Lett., 33, L14809, doi:10.1029/2006GL026021, 2006.

Shao, H. and Liu, G.: A critical examination of the observed first aerosol indirect effect, J. Atmos. Sci., 66, 1018-1032, 2009.

Stevens, B. and Feingold, G.: Untangling aerosols effects on clouds and precipitation in a buffered system, Nature, 461, 607-613, doi:10.1038/nature08281, 2009.
Twomey, S.: Pollution and the planetary albedo, Atmos. Environ., 8, 1251-1256, 1974.

Wang, J., Daum, P. H., Yum, S. S., Liu Y., Senum, G. I., Lu, M.-L., Seinfeld, J. H., and Jonsson, H.: Observations of marine stratocumulus microphysics and implications for processes controlling droplet spectra. Results from the Marine Stratus/Stratocumulus Experiment, J. Geophys. Res., 114, D18210, doi:10.1029/2008JD011035, 2009. 